\title{
Professor Dr. Rudolf E. Kaiser (1930-2021)
}

Bernd Spangenberg ${ }^{1}$

๑) Akadémiai Kiadó, Budapest, Hungary 2021

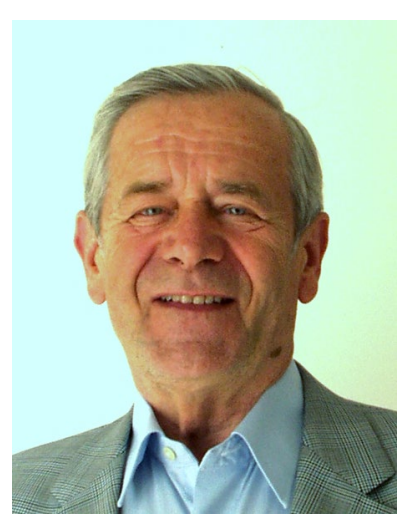

Rudolf Ernst Kaiser passed away on August 6, 2021, after a short, serious illness. In a touching funeral service, the pastor paid tribute to Rudolf as an impressive person who always got up again, who always started something new.

Rudolf E. Kaiser was born 1930 in Teplitz-Schönau (now in the Czech Republic) and grew up there, but had to leave northern Bohemia with his parents as displaced persons in 1945. His fascinating career began at the age of 17 , when he started working as a technical manager in the paint and varnish factory in Zittau founded by his father in 1946. Despite his father's early death in 1949, he completed his chemistry studies in war-torn Dresden and his doctorate at Leipzig University in record time at the age of 24 .

At the age of 29, he was appointed as the youngest head of department at the German Academy of Sciences in Berlin and worked at the Institute of Industrial Chemistry in Leipzig. Here, he wrote his first technical book on chromatography, which was also translated into English and Russian. This book immediately made him known in the international scientific community. He was invited to seminars and lectures at the leading universities and research institutes in

Bernd Spangenberg

spangenberg@hs-offenburg.de

1 Offenburg University, Offenburg, Germany
Russia, where he presented his outstanding research results in the field of chromatography. In 1960, Rudolf Kaiser had only one hour to leave the German Democratic Republic with his wife and two children because he refused to spy on Western scientists during his numerous business trips abroad.

The family emigrated to the Federal Republic of Germany, where Kaiser was soon employed by BASF in Ludwigshafen. There he introduced capillary gas chromatography (GC) and set up a high-performance GC laboratory. At that time, there were no industrial capillary GC instruments on the market, and Kaiser developed such an instrument for in-house series production. In the late 1960s, Kaiser started environmental measurements at BASF at a time when the term "environmental analysis" did not yet exist. In 1960/61, he published his book series "Chromatography in the Gas Phase," which appeared in several editions (in German and English).

In 1972, he went business for himself and founded the Institute for Chromatography in Bad Dürkheim near Ludwigshafen. He became one of the world's leading experts in the field of chromatography and his institute an international recognized research and training center. More than 7,000 analysts from 55 countries attended his seminars. His expertise as a publicly appointed expert for environmental analysis and measurement technology was in demand. After the fall of the "Iron Curtain" in 1989, Rudolf E. Kaiser founded the "International Foundation for Environmental Assistance for Russia." He did this together with his second wife Olga — a scientist at Moscow State University — whom he married after the death of his first wife Annemarie. Both worked intensively with the Russian chemical, oil and gas industries in the field of advanced training, method development and analytical problem solving. During this cooperation, hundreds of colleagues from Russia visited the Institute for Chromatography.

His motivation to fully share his acquired knowledge runs like a thread through his life. He has published more than a 100 papers and over 20 books. He gave lectures in Houston (Texas, USA), among other places, and gave advanced 
training courses in many countries. He founded worldfamous symposia and international journals, then, as now, completely unusual, as a private person. In 1968, he founded the well-known international journal Chromatographia, in 1978 the Journal of High-Resolution Chromatography and Chromatography Communication, and in 1983 the Computer Application in the Laboratory. In 1988, he played the key role in the founding of the Journal of Planar Chromatography $(J P C)$. He also worked as Editor-in-Chief or as an Editorial Board member of these journals.

He started the following series of Symposia and was their chairman for many years:

- International Symposium on Capillary Chromatography (since 1975: Hindelang, now Riva del Garda, Italy). It is the world's most important GC symposium and will be held for the 44th time in Riva del Garda in 2022.

- International Symposium on Planar Chromatography (since 1980: Bad Dürkheim, then Interlaken, Switzerland and Budapest, Hungary).

His achievements in chromatography have been recognized by a number of awards:

- Tswett Medal of the Russian Academy of Sciences-as the first foreign recipient (Moscow, Soviet Union, 1978);

- Gold Medal of the Chinese Academy of Sciences and Chinese Chemical Society (Beijing, People's Republic of China, 1988);

- A.J.P. Martin Award (Brighton, United Kingdom, 1989); Marcel Golay Award (Riva del Garda, Italy, 1989);

- Tswett Medal of the Chromatographic Society of Russia (Düsseldorf, 1995);

- 1 st Class German Distinguished Medal for his contribution to environmental analysis and for his international activities in this field (Berlin, 1996);

- Clemens Winkler Medal of the Gesellschaft Deutscher Chemiker (GDCh) (Munich, 2010).
Rudolf E. Kaiser was a scientist through and through. After retirement, he was still improving circular chromatography in his living room to identify counterfeit drugs. He was proud to perform chromatography at a high level with absolutely simple equipment, even without a laboratory. For him, this was proof of the superiority of planar chromatography. When I have visited Olga and Rudolf in recent years, he asked me more and more often to select books from his large library on chromatography. Being a good academic, he could not throw away the books and was glad to see them in use. With some books, he was reluctant to give them away, but I got them. Only the first issue of JPC he kept; he could not part with that one.

The chromatography community planned to celebrate Kaiser's $90^{\text {th }}$ birthday in June 2020 in Ljubljana, but due to the SARS-CoV-2 pandemic this was postponed. In his last e-mail to me, he looked forward to seeing everyone in Ljubljana in June 2022. He ended his e-mail with a game of words meaning "stay healthy." The fateful diagnosis of lung cancer put an end to his future plans.

Prof. Dr. Rudolf Kaiser was a person of free spirit who did not allow himself to be restricted in his personal and scientific freedom by anything or anyone. His death has made the chromatography community poorer.

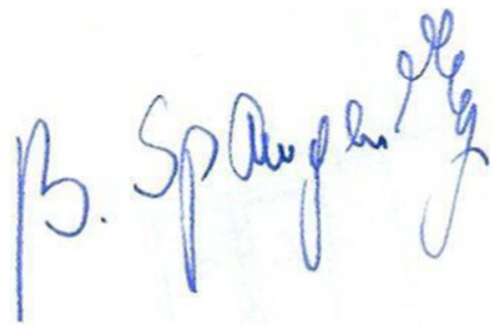

Bernd Spangenberg (Editor-in-Chief) 